\title{
FutureJournal
}

\section{Qualificação Profissional ou Competências para o Mercado Futuro?}

\author{
Yluska Bambirra Assunção \\ Mestre em Administração pelo Centro Universitário UNA, Brasil
}

Iris Barbosa Goulart

Doutorado em Psicologia pela Pontifícia Universidade Católica de São Paulo, Brasil

\section{RESUMO}

As mudanças ocorridas no mundo do trabalho desde a segunda metade do século XX têm obrigado os gestores a definirem novas formas de selecionar e desenvolver os trabalhadores. Nesse contexto, ganharam espaço as discussões sobre os processos de qualificação profissional e de identificação de competências. Este artigo constitui um estudo teórico, que contribui para o entendimento conceitual acadêmico dos construtos qualificação profissional e competência e estimula o debate e a pesquisa sobre quais competências serão as mais relevantes para empresas no futuro. A partir da análise histórica e da evolução desses conceitos, torna-se mais clara a distinção entre eles, tanto na perspectiva francesa quanto na americana. Discutemse as interfaces com o cenário contemporâneo e prioriza-se a abordagem americana das competências, modelo mais utilizado no Brasil. Neste texto pretende-se identificar aspectos das competências que contemplem o cenário contemporâneo do mundo do trabalho e, em face das características das empresas do futuro, mencionadas na literatura, comenta-se a convergência entre as competências individuais (conhecimentos, habilidades e atitudes) e o atendimento às demandas futuras do mercado de trabalho.

PALAVRAS-CHAVE: Competências individuais. Qualificação profissional. Conhecimentos. Habilidades. Atitudes. 


\section{Professional training or competencies for the future?}

\section{ABSTRACT}

The changes in the labor market since the second half of the twentieth century have forced managers to define new ways of selecting and developing employees. In this context, they gained ground discussions on occupational training and competencies identification. This article is a theoretical study, which contributes to the academic conceptual understanding of the constructs professional qualification and competency and stimulates debate and research about which competencies will be most relevant to companies in the future. From the historical analysis and the evolution of these concepts, it becomes clearer the distinction between them, both in French and in American perspective. Interfaces are discussed with the contemporary setting and gives priority to American approach of competency, most widely used model in Brazil. The text aims to identify aspects of competency that address the contemporary setting of the working world and, given the characteristics of the future companies, mentioned in the literature, comments on the convergence of individual competencies (knowledge, skills and attitudes) and meeting future demands labor market.

KEY-WORDS: Competency. Occupational training. Knowledge. Skill. Attitude. 


\section{INTRODUÇÃO}

As mudanças que ocorreram no mundo do trabalho, decorrentes, principalmente, do desenvolvimento tecnológico, da imprevisibilidade dos problemas emergentes nas empresas e da consequente adoção de novos modelos de gestão, têm levado os gestores a repensar os critérios para a seleção e o desenvolvimento das pessoas no trabalho. Esse contexto, no qual se evidencia a situação de imprevisibilidade e instabilidade do mundo do trabalho contemporâneo, estimula uma necessidade de revisão das competências requeridas dos profissionais que atuarão nas empresas do futuro.

A visibilidade que o conceito de competência tem assumido, nacional e internacionalmente, em face de uma sociedade em constante mudança, alicerçada na complexidade e na imprevisibilidade, é destacada por Sá e Paixão (2013). Le Boterf (2003) afirma que o sentido mais tradicional da noção de competência já não permite compreender os novos desafios colocados pelo século XXI, permeados de complexidade e interdependência. Esses autores ressaltam a significância de uma nova perspectiva para os profissionais no futuro.

Mudanças no mundo do trabalho, como a transição da engenharia de tarefas para a globalização e a velocidade do desenvolvimento científico e tecnológico, alteraram a forma de produção e aguçaram a competitividade nos negócios. Para incorporarem valores que melhor atendessem às necessidades e expectativas dos clientes, as empresas acabaram impactando significativamente na formação e capacitação das pessoas para os empregos, exigindo cada vez mais dos profissionais (Malvezzi, 1999). Barbosa e Cintra (2012, p. 39) concordam que "a reflexão quanto aos fatores que asseguram a competitividade, na atualidade evidencia um movimento que passa a considerar as competências como um diferencial competitivo".

Mudanças no ambiente interno das empresas também apontam mudanças no mundo do trabalho. Emerge o perfil dos funcionários da geração Y, que, segundo Lombardia, Stein e Pin (2008), são pessoas nascidas entre o final da década de 1970 e meados da década de 1990, época marcada por características relacionadas com o ritmo de mudança, a necessidade e o grau 
de interatividade, o acesso à informação e o entendimento do mundo, que, em conjunto, definem uma nova forma de ser e de agir na sociedade, com reflexos significativos no mundo do trabalho. Essa geração mostra-se mais impaciente, multitarefa e polivalente. Segundo Calvosa, Vilhena, Xavier e Xavuem (2012), tem-se verificado que as pessoas dessa geração valorizam menos a permanência em uma única empresa, têm nível mais elevado de formação e destacam que o que pode fazer diferença no mercado é o fato de se preocuparem com a constante reciclagem dos conhecimentos, praticarem tudo o que aprendem, se tornarem cada vez mais hábeis e não terem medo de ter atitude, aproximando a relação direta entre competência e empregabilidade.

Alguns dos desafios que se apresentam para as organizações atualmente, e que ganharão espaço também no futuro, incluem a globalização, os espaços físicos, a tecnologia e os funcionários.

As oportunidades de trabalho começam a romper as fronteiras físicas do escritório; a virtualidade passa a fazer cada vez mais parte do cotidiano dos trabalhadores que têm à mão aparelhos eletrônicos como smartphones e tablets, que possibilitam o acompanhamento dos acontecimentos em tempo real, estejam em bares e restaurantes ou enquanto caminham pelas ruas.

As transformações nas carreiras profissionais também impactam no mundo contemporâneo e no futuro do trabalho. Segundo Malvezzi (1999), o modelo emergente de carreira implica uma mobilidade irregular e imprevisível na qual os indivíduos trilham seu caminho guiados a partir das próprias competências. A carreira em espiral apresenta-se como mais um dos aspectos que impactam o desenvolvimento profissional, pois a ascensão não está mais ligada apenas a uma área de conhecimento ou ao "tempo de casa".

A revisão das competências requeridas dos profissionais nos próximos anos implica uma nova postura/proposta dos diversos elos do mundo do trabalho que pede mais agilidade, flexibilidade e inovação das empresas e dos profissionais (Manfredi, 1999; Borges \& Yamamoto, 2014; Lawer \& Worley, 2010).

Em sua dimensão individual, a noção de competências inicia sua construção em um ambiente de aumento de concorrência, incertezas e imprevisibilidade de mercado, aceleração e ampliação de informações, diminuição do trabalho formal e crescimento dos trabalhos descontínuos e informais, 
surgimento da economia de serviços e organização do trabalho com foco em responsabilidades e resultados. Nesse contexto, surge a necessidade de formar pessoas que consigam mobilizar suas competências, conforme situações específicas, que se fazem presentes em determinados ambientes (Barbosa \& Cintra, 2012, p. 47).

Diante do reconhecimento de que as competências estão relacionadas com a vida profissional e com o mundo do trabalho contemporâneo, neste estudo aprofunda-se o resgate histórico dos conceitos de qualificação profissional e de competências, buscando suas possíveis articulações com esse mercado dinâmico e exercitando um cenário futuro, pautado em produções acadêmicas das novas características requeridas pelo mercado.

\section{REVISÃO DE LITERATURA}

\subsection{A EVOLUÇÃO DO CONCEITO DE QUALIFICAÇÃO PROFISSIONAL} PARA O CONCEITO DE COMPETÊNCIA

Neste tópico resume-se a história do desenvolvimento profissional, abordando a trajetória da qualificação à competência, explicitando suas diferenças e possibilidades sob as perspectivas das escolas francesa e americana e apresentando, nos recortes temporais, suas representações ou reflexos no Brasil.

Encontram-se várias definições, assim como vários debates, para o tema competência (Perrenoud, 1999, p. 7; Manfredi, 1999, p. 15; Fleury \& Fleury, 2001). Para não incorrer em negligência, foram estudados diversos autores e suas conceituações acerca do tema competência, apresentadas a seguir.

Durante o século XIX, as habilidades eram adquiridas durante a realização do trabalho, ao longo da trajetória profissional, com treinamentos sistemáticos, conforme descrevem Borges e Yamamoto (2014, p. 35), o trabalhador que repetia seus movimentos ininterruptamente era treinado na "fábrica de adestramento de indivíduos" para garantir a rapidez, a exatidão e a produtividade de acordo com os objetivos organizacionais. 
Na Europa, Dugué (2004, p. 20) apresenta as Corporações de Ofício como as instituições formadoras dos profissionais antes da guerra, cujas regulações eram autoritárias e rígidas: "(...) no Antigo Regime, essas corporações codificavam as relações (regras de contratação, salário, formação) entre mestres, companheiros e aprendizes, de maneira a permitir a competição, mas também controlar seus efeitos". Na Figura 1, a seguir, representa-se essa forma de educação profissional.

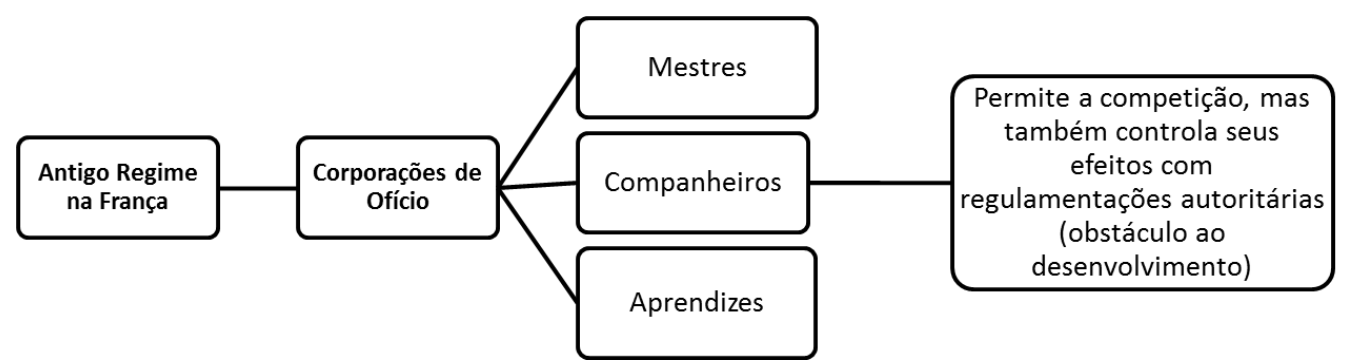

Figura 1: Corporações de Ofício

Fonte: Elaborada pela autora

De acordo com Dugué (2004), no período pós-guerra, por volta de 1945, com a falta de pessoas qualificadas para realização das tarefas, a regra da oferta e da procura substitui as regulamentações autoritárias. Com isso, apesar do impulso econômico, dois grandes problemas marcam o século XIX, a partir dos quais surge a noção de qualificação, conforme se apresenta e destaca na Figura 2.

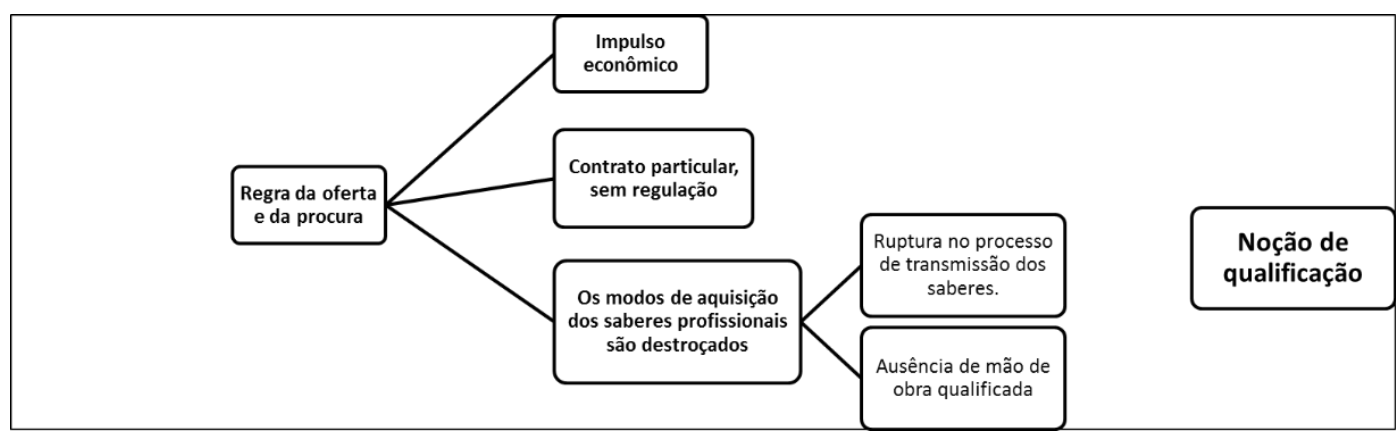

\section{Figura 2: Noção de qualificação}

Fonte: Elaborada pela autora

No contexto pós-guerra na Europa, instalam-se dois sistemas que reforçam a noção da qualificação (Dugué, 2004): 
- as convenções coletivas, que classificam e hierarquizam os postos de trabalho, participam da regulação da relação salarial, institucionalizam a noção de qualificação do trabalho e fundam a correspondência entre saber-fazer, emprego e salário;

- o ensino profissional, que classifica e organiza os saberes em tomo dos diplomas, reforçando a noção de qualificação.

Uma vez qualificadas, as pessoas recebiam seus diplomas, passaporte para os empregos nas indústrias, empregos que se estendiam por cerca de 30 anos (Dugué, 2004).

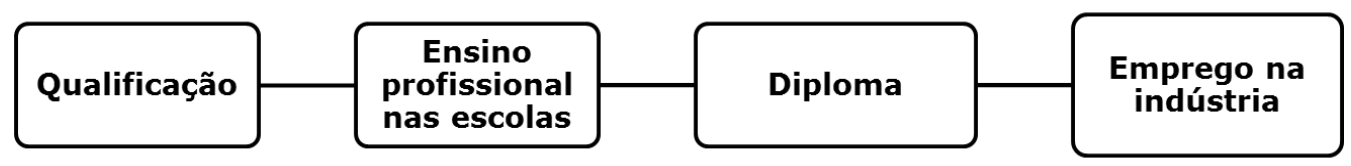

\section{Figura 3: Caminho certo para o emprego}

Fonte: Elaborada pela autora

No Brasil, foi aprovado em 1906 um crédito do governo federal para que os estados criassem escolas técnicas profissionais. "As Escolas de Ofícios, até então denominadas Escolas de Aprendizes Artífices, passaram a ser chamadas de Liceus e destinadas ao ensino profissional de todos os ramos e graus" (Garcia, 2000, p. 7). Mais tarde, passaram a chamar-se Escolas Técnicas Federais, um sistema de ensino paralelo ao sistema oficial, que foi organizado em convênio com as indústrias, por meio da Confederação Nacional das Indústrias (CNI). Originava-se, em 1946, o Sistema "S" (Senai, Senac, Sebrae, etc.), no intuito de formar mão de obra qualificada no Brasil, empenho justificado pelo aumento de indústrias no país após a guerra (Garcia, 2000).

A qualificação, até então traduzida como sinônimo de preparação de "capital humano", começa a perder sentido, conforme descreve Manfredi (1999, p. 20):

Esta concepção de qualificação hegemônica (...) ancorada nos modelos taylorista e fordista de organização da produção e do trabalho, entra em crise com a reorganização do sistema capitalista por intermédio da adoção de sistemas de produção flexíveis e da criação de novas formas de organização do trabalho. 
A noção de qualificação torna-se alvo de críticas na Europa e o primeiro limite é o impedimento à evolução profissional por não resolver a questão do reconhecimento dos saberes adquiridos no trabalho, pois, uma vez restritos à execução no âmbito do diploma, os profissionais não tinham como crescer profissionalmente. A partir dos anos 1970, o sistema de qualificação profissional é afrontado de maneira ainda mais evidente devido a sua não adaptação às grandes evoluções do sistema de produção (Dugué, 2004).

O sistema da qualificação foi bem adaptado às organizações estáveis, de tipo taylorista, mas muito menos às organizações mais flexíveis. Portanto, à medida que ocorrem mudanças nas empresas, o que foi ensinado já não tem mais aplicabilidade e o sistema da qualificação aparece como um sistema limitado. A qualificação acaba por tornar-se "um obstáculo que impede a adaptação da mão de obra às exigências do aparelho de produção" (Dugué, 2004 , p. 23). "Aos poucos, novas ideias e um novo vocabulário foram sendo incorporados no quotidiano das empresas brasileiras e prepararam o terreno para incorporação do conceito de competência" (Fleury \& Fleury, 2001, p. 10).

Diante da insuficiência do sistema de qualificação tecnicista (cuja matriz é o modelo job/skills) frente às novas condições de produção e à chamada Era do Conhecimento, emerge na França o conceito de competências, em que se recorre não mais somente aos conhecimentos, mas também à valorização do capital intelectual e à mobilização psíquica para a ação dos trabalhadores (Manfredi, 1999; Leite \& Goulart, 2006).

Apesar de diversos autores concordarem com a ruptura da qualificação, com relação à terminologia "competência", não existe consenso na literatura científica. Manfredi (1999) e Hirata (1994) acreditavam na ampliação do conceito de qualificação, ressignificando-o, mas, mesmo assim, reconheceram a polissemia da noção de competência. Por outro lado, Ramos (2006) e Zarifian (2001) diferenciam o significado de competência daquele de qualificação, apontando algumas dimensões da qualificação que seriam negadas e outras afirmadas, simultaneamente, no conceito de competências. Já para Vieira e Ribeiro da Luz (2005), na noção de competência enfatiza-se a dimensão experimental da qualificação. O que se tem por congruente é a 
inexistência de um modelo absoluto de competência, característica de sua relatividade, sujeita às contingências.

Duas linhas conceituais são consideradas as principais e serão abordadas neste artigo: a escola francesa, representada por Zarifian, Le Boterf e Perrenoud, e a escola americana, representada por McClelland, Boyatzis e Spencer \& Spencer.

Resumidamente, enquanto a escola americana se preocupa com a questão da entrega da pessoa para o trabalho em busca de desempenho superior em determinado cargo ou função, a escola francesa também associa o conceito de competência a essa entrega, porém de forma independente de algum cargo, isto é, para a própria pessoa. Ambas consideram o contexto como fator fundamental para balizar os comportamentos aceitáveis (Dutra, 2004).

A seguir apresenta-se no Quadro 1, um resumo dos conceitos de qualificação e competência segundo os autores que são referências nos respectivos temas.

\begin{tabular}{|c|c|}
\hline 0 & \\
\hline $\begin{array}{l}\text { A qualificação apresenta três dimensões: } \\
\text { (1) conceitual, que associa os processos } \\
\text { de formação ao valor dos diplomas } \\
\text { (status e remuneração); (2) social, que }\end{array}$ & $\begin{array}{l}\text { A noção de competência enfatiza a dimensão } \\
\text { experimental e enfraquece as dimensões } \\
\text { conceitual e social da qualificação (Vieira \& } \\
\text { Ribeiro da Luz, 2005). }\end{array}$ \\
\hline $\begin{array}{l}\text { relaciona o processo de formação com o } \\
\text { reconhecimento social do ofício; (3) } \\
\text { experimental, na qual a formação é } \\
\text { associada à valorização das qualidades } \\
\text { dos indivíduos (atributos pessoais, } \\
\text { potencialidade e valores) (Ramos, } \\
2006 \text { ). }\end{array}$ & $\begin{array}{l}\text { A competência é entendida como um } \\
\text { conjunto de conhecimentos, habilidades e } \\
\text { atitudes que definirão um desempenho } \\
\text { superior (Spencer, McClelland \& Spencer } \\
\text { 1994). }\end{array}$ \\
\hline $\begin{array}{l}\text { Sinônimo de preparação de "capital } \\
\text { humano", qualificação hegemônica } \\
\text { ancorada nos modelos taylorista e } \\
\text { fordista de organização da produção e do } \\
\text { trabalho. Não se adequa ao modelo da } \\
\text { adoção de sistemas de produção flexíveis } \\
\text { e da criação de novas formas de }\end{array}$ & $\begin{array}{l}\text { Diante da insuficiência do sistema de } \\
\text { qualificação tecnicista (cuja matriz é o } \\
\text { modelo job/skills) frente às novas condições } \\
\text { de produção e à chamada Era do } \\
\text { Conhecimento, emerge na França o conceito } \\
\text { de competências, no qual não se recorre } \\
\text { mais somente aos conhecimentos, mas }\end{array}$ \\
\hline
\end{tabular}




\begin{tabular}{|l|l|l|}
\hline $\begin{array}{l}\text { organização do trabalho (Manfredi, } \\
\text { 1999). }\end{array}$ & $\begin{array}{l}\text { também à valorização do capital intelectual e } \\
\text { à mobilização psíquica para a ação dos } \\
\text { trabalhadores (Manfredi, 1999; Leite \& } \\
\text { Goulart, 2006). }\end{array}$
\end{tabular}

(continua)

(continuação)

\begin{tabular}{|c|c|}
\hline $\begin{array}{l}\text { Advém do ensino profissional, que } \\
\text { classifica e organiza os saberes em torno } \\
\text { dos diplomas que eram passaporte para } \\
\text { os empregos nas indústrias. Bem } \\
\text { adaptado às organizações estáveis, de } \\
\text { tipo taylorista, e muito menos às } \\
\text { organizações mais flexíveis, acaba por } \\
\text { gerar um impedimento à evolução } \\
\text { profissional por não reconhecer os } \\
\text { saberes adquiridos no trabalho, pois, } \\
\text { uma vez restritos à execução no âmbito } \\
\text { do diploma, os profissionais não tinham } \\
\text { como crescer profissionalmente. Os } \\
\text { diplomas validam saberes e são } \\
\text { adquiridos de uma vez por todas, dando } \\
\text { à noção de qualificação uma dimensão } \\
\text { estabilizadora (Dugué, 2004). }\end{array}$ & $\begin{array}{l}\text { As competências são definidas como } \\
\text { "saberes em ação"; um conjunto de } \\
\text { conhecimentos e de maneiras de ser que se } \\
\text { combinam harmoniosamente para } \\
\text { responder às necessidades de uma dada } \\
\text { situação em um dado momento. Remetem } \\
\text { a uma mistura de saber e de } \\
\text { comportamento que confere um lugar } \\
\text { preponderante ao "saber-ser" e ao } \\
\text { investimento psicológico. Competência, por } \\
\text { definição é "inqualificável", é da ordem do } \\
\text { conjuntural e não pode ser considerada um } \\
\text { atributo definitivo (Dugué, 2004). }\end{array}$ \\
\hline $\begin{array}{l}\text { Sistema de ensino paralelo ao ensino } \\
\text { formal com o intuito de formar mão de } \\
\text { obra qualificada (Garcia, 2000). }\end{array}$ & $\begin{array}{l}\text { As competências são aquisições, } \\
\text { aprendizados construídos. A aquisição de } \\
\text { experiências leva tempo, são construídas } \\
\text { lentamente à medida que uma pessoa } \\
\text { enfrenta situações (Perrenoud, 1999). }\end{array}$ \\
\hline $\begin{array}{l}\text { Essencialmente relacionado a aspectos } \\
\text { técnicos do posto de trabalho, passíveis } \\
\text { de serem atestados por um certificado } \\
\text { emitido por uma instituição socialmente } \\
\text { reconhecida (Leite \& Goulart, 2006) }\end{array}$ & $\begin{array}{l}\text { Competência deve ser entendida como a } \\
\text { responsabilidade que o empregado assume } \\
\text { diante das situações produtivas, um } \\
\text { entendimento prático de situações que se } \\
\text { apoia em conhecimentos adquiridos e os } \\
\text { transforma na medida em que aumenta a } \\
\text { diversidade das situações (Zarifian, } 20101\end{array}$ \\
\hline
\end{tabular}




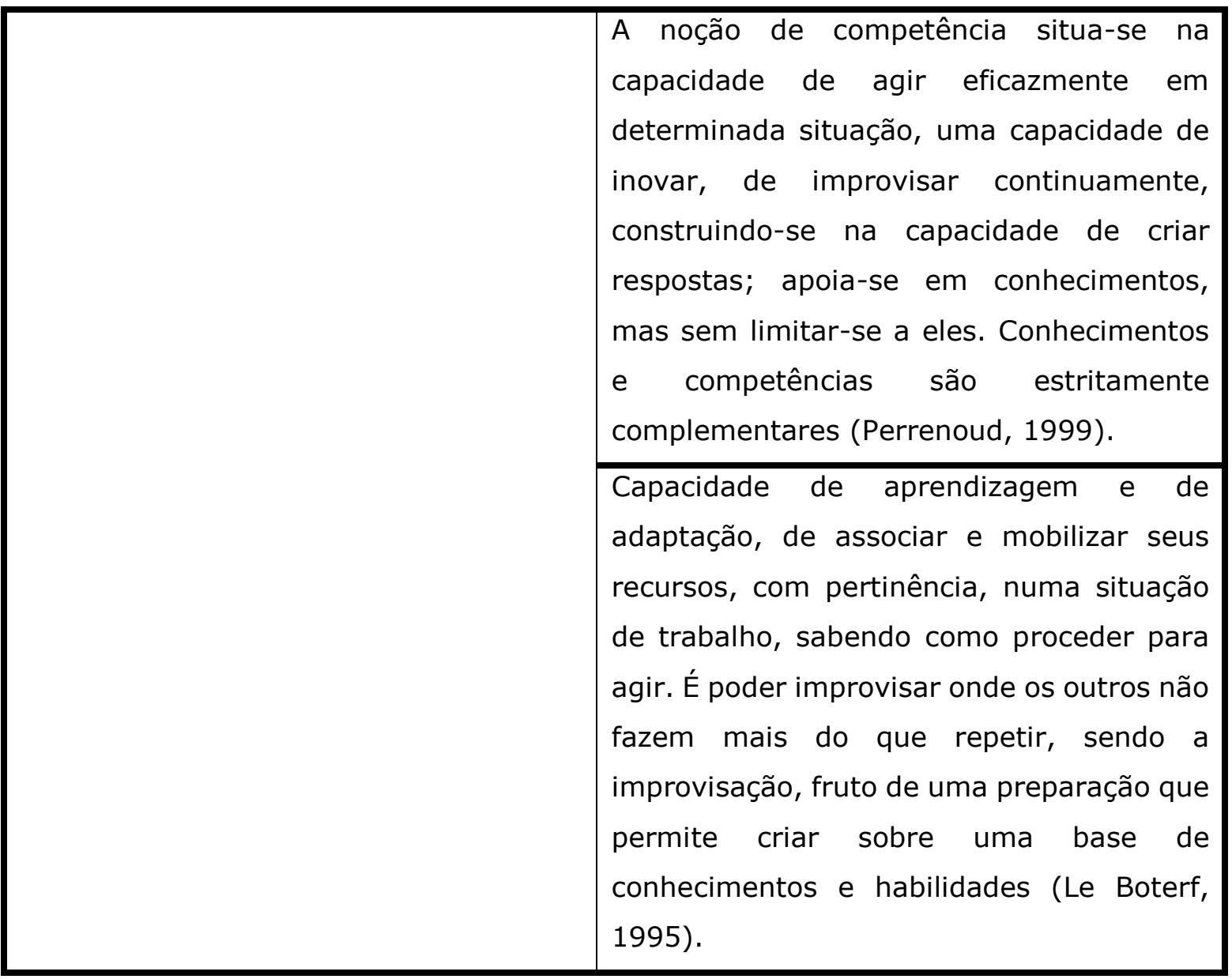

\section{Quadro 1: Conceitos de qualificação e competência}

Fonte: Elaborado pela autora

\subsection{COMPETÊNCIA NA PERSPECTIVA FRANCESA}

Na escola francesa, Perrenoud (1999, p. 7) define competência como "uma capacidade de agir eficazmente em um determinado tipo de situação, apoiada em conhecimentos, mas sem limitar-se a eles". A aquisição de experiências leva tempo e as competências são construídas lentamente à medida que uma pessoa enfrenta situações, ou seja, conhecimentos e competências são complementares. O autor apresenta três concepções clássicas como "versões aceitáveis" da noção de competência: (1) a transferência de conhecimentos por meio do ensino-aprendizagem, o objetivo do ensino com fins de certificação (que o autor considera superado); (2) outra concepção relacionaria competência a desempenho, sendo este um indicador mais ou menos confiável de competência; (3) finalmente, a que considera a competência como uma faculdade genérica, característica da espécie 
humana, como uma capacidade de inovar, de improvisar continuamente, construindo-se na capacidade de criar respostas (Perrenoud, 1999, p. 10).

Dugué (2004, p. 24) corrobora os autores, ainda considerando a competência como "saberes em ação", ou seja, "um conjunto de conhecimentos e de maneiras de ser que se combinam harmoniosamente para responder às necessidades de uma dada situação em um dado momento". Segundo a autora, enquanto os diplomas validam saberes e a qualificação apresenta uma dimensão estabilizadora, as competências remetem a uma mistura de saber e de comportamentos que está na ordem do conjuntural e, portanto, não podem ser consideradas um atributo definitivo.

Zarifian (2001, p. 62) observa o surgimento de um novo modelo de gestão de mão de obra ao qual denomina "modelo de competências", que se baseia na responsabilização do indivíduo, ou seja, "competência deve ser entendida, em primeiro lugar, como a responsabilidade pessoal que o empregado assume diante das situações produtivas", mas também "um entendimento prático de situações que se apoia em conhecimentos adquiridos e os transforma na medida em que aumenta a diversidade das situações" (Zarifian, 2001, p. 62).

De forma similar, a definição de competência trazida por Le Boterf (1995) valoriza o indivíduo e pressupõe sua capacidade de aprendizagem e de adaptação, de associar e mobilizar seus recursos, com pertinência, numa situação de trabalho, sabendo como proceder para agir; "é poder improvisar onde os outros não fazem mais do que repetir", sendo a improvisação, fruto de uma preparação, capaz de permitir ao indivíduo criar sobre uma base de conhecimentos e habilidades. Segundo esse autor, as competências aumentam a empregabilidade, porém são, por si só, invisíveis, dependendo de as pessoas a colocarem em ação para que ela (a competência) exista. 0 essencial da competência, no seu ponto de vista, é "saber mobilizar" seus recursos para agir em um contexto profissional determinado" (Le Boterf, 2003, p. 11).

Le Boterf (2006, p. 61) apresenta três dimensões da competência:

Primeiro, a dimensão dos recursos disponíveis (conhecimentos, saber-fazer, capacidades cognitivas, competências comportamentais...) que ele pode 
mobilizar para agir; depois, surge a dimensão da acção e dos resultados que ela produz, isto é, a das práticas profissionais e do desempenho. Finalmente, há a dimensão da reflexividade, que é a do distanciamento em relação às duas dimensões anteriores.

Com relação à reflexividade e ao distanciamento, o profissional competente deve tomar consciência de suas práticas, na visão de Le Boterf (2006, p. 62), deve "possuir uma dupla compreensão: a da situação sobre a qual intervém e a forma como o faz". Essa inteligência das situações e esse conhecimento dele próprio pressupõem um distanciamento, necessário para melhorar suas práticas profissionais. O autor ainda distingue o "saber agir" do "saber-fazer", referindo-se ao fato de que saber-agir pode significar, algumas vezes, não agir.

Contudo, essa definição apresenta limitações no ponto de vista de Zarifian (2001) que, então, apresenta uma definição multidimensional de competência alimentada por três aspectos:(1) a tomada de iniciativa é responsabilidade do indivíduo; (2) o entendimento prático das situações, que se apoia nos conhecimentos adquiridos e os transforma à medida que aumenta a diversidade das situações; (3) a faculdade de mobilizar redes de atores em torno das mesmas situações (Zarifian, 2001, p. 68).

Entretanto, existem dificuldades e limites suscitados por essa "nova lógica", considerados por Hirata (2001) precondições para o desenvolvimento e a adoção do sentido mais amplo do conceito de competência, a saber: segurança e estabilidade no emprego, abertura para que o trabalhador adote uma postura reflexiva em relação a sua atividade (estudar e pensar), aprofundamento da formação geral e profissional e pleno reconhecimento salarial e simbólico.

\subsection{COMPETÊNCIA NA PERSPECTIVA AMERICANA}

Dutra (2004) apresenta o surgimento da noção de competência na perspectiva da escola americana:

A base desse conceito é o deslocamento do foco que estava sobre o estoque de conhecimentos e habilidades para a forma como a pessoa mobilizava seu estoque e repertório de conhecimentos e habilidades em determinado contexto, de modo a agregar valor para o meio no qual se inseria. O conceito de competência foi 
proposto de forma estruturada pela primeira vez em 1973 por Davis McClelland (Dutra, 2004, p. 22).

A partir de um estudo realizado para argumentar sobre a validade dos instrumentos de mensuração das características fixas para efeitos de seleção de pessoas, McClelland (1973) introduz o construto competências e ressalta que a principal diferença em relação à perspectiva francesa, com foco na construção de um conceito para compreender as mudanças na formação profissional, seria a metodologia da gestão de competências ou técnicas bem definidas. Essa abordagem rapidamente foi absorvida pelas empresas e propagou-se por sua característica coerente com a do mercado capitalista (Fleury \& Fleury, 2001; Dutra, 2004; Leite \& Goulart, 2006).

Diferentemente da abordagem francesa, a literatura americana a respeito do tema competência apresenta o desempenho superior como maior preocupação. Competência "é uma combinação de conhecimentos, habilidades e desempenho... a capacidade de aplicar conhecimentos, habilidades e julgamento na prática. A integração simultânea de conhecimentos, habilidades e atitudes necessários para o desempenho em um papel designado e definido" (Spencer, McClelland \& Spencer, 1994).

Dessa forma, a análise de um "modelo de competências" na perspectiva da escola americana consistiria na identificação de comportamentos e características de personalidade que distinguem 0 desempenho superior de uma pessoa para realizar determinada tarefa. Apesar das várias formas de definição, em sua essência, são apresentados como elementos ou pilares da competência que passaram a ser conhecidos como CHA (Fleury \& Fleury, 2001; Leite \& Goulart, 2006):

- conhecimentos: constituem o conjunto de informações, saberes associados à experiência, à intuição e aos valores;

- habilidades: capacidade do indivíduo de aplicar seu conhecimento na prática; é o saber-fazer;

- atitudes: avaliação afetivo-cognitiva da realidade, que determina posturas e comportamentos, "prontidões" de comportamento.

Entretanto, a noção de competências na perspectiva americana também recebe críticas que se referem ao fato de que estas estão relacionadas apenas ao indivíduo e a um conjunto de atribuições relacionadas 
aos cargos que ocupam. Dessa forma, estariam apenas dando nova roupagem dos princípios tayloristas e fordistas em uma versão moderna (Fleury \& Fleury, 2001).

No Quadro 2, a seguir, sintetiza-se o conceito de competência, sob as diferentes perspectivas.

\begin{tabular}{|c|c|c|c|}
\hline $\begin{array}{c}\text { Perspectiva } \\
\text { francesa }\end{array}$ & $\begin{array}{l}\text { Autores de } \\
\text { referência }\end{array}$ & $\begin{array}{l}\text { Perspectiva } \\
\text { americana }\end{array}$ & $\begin{array}{l}\text { Autores de } \\
\text { referência }\end{array}$ \\
\hline $\begin{array}{l}\text { Pressupõe } \\
\text { capacidade das } \\
\text { pessoas de } \\
\text { aprendizagem e de } \\
\text { adaptação, } \\
\text { sabendo mobilizar } \\
\text { seus recursos para } \\
\text { agir em um } \\
\text { contexto } \\
\text { profissional. } \\
\text { Associa o conceito } \\
\text { de competência à } \\
\text { entrega, porém de } \\
\text { forma } \\
\text { independente de } \\
\text { algum cargo, isto } \\
\text { é, para a própria } \\
\text { pessoa, } \\
\text { considerando o } \\
\text { indivíduo, sua } \\
\text { subjetividade } \\
\text { sua experiência. }\end{array}$ & $\begin{array}{l}\text { Le Boterf } \\
\text { Zarifian } \\
\text { Dugué } \\
\text { Perrenoud }\end{array}$ & $\begin{array}{l}\text { Preocupa-se com a } \\
\text { questão da } \\
\text { entrega da pessoa } \\
\text { para o trabalho em } \\
\text { busca de um } \\
\text { desempenho } \\
\text { superior } \\
\text { determinado cargo } \\
\text { ou função. É a } \\
\text { integração } \\
\text { simultânea } \\
\text { conhecimentos, de } \\
\text { habilidades } \\
\text { atitudes } \\
\text { necessários para o } \\
\text { desempenho em } \\
\text { um papel } \\
\text { designado } \\
\text { definido. }\end{array}$ & $\begin{array}{l}\text { McClelland } \\
\text { Boyatzis } \\
\text { Spencer \& } \\
\text { Spencer. }\end{array}$ \\
\hline
\end{tabular}

\section{Quadro 2: Competência nas perspectivas francesa e americana}

Fonte: Elaborado pela autora

\subsection{UMA VISÃO CONTEMPORÂNEA DAS COMPETÊNCIAS NO BRASIL}

Vieira e Ribeiro da Luz (2005) relatam que o conceito de competência, nos anos de 1980, foi entendido como o mais adequado para os empresários. O modelo seria capaz de atender às demandas do novo contexto instaurado, 
de forte desenvolvimento tecnológico e reorganização do trabalho, caracterizado pela flexibilização da produção, integração de setores, multifuncionalidade e polivalência dos trabalhadores e valorização dos saberes não ligados ao trabalho prescrito. O início da consolidação da noção de competência se dá na transição do conceito de qualificação para o de competência migrando da "identificação das capacidades necessárias para atuar em certo tipo de tarefa para obter um desempenho superior" (Dutra, Fleury \& Ruas, 2008, p. 25).

Entre os anos de 1980 e 2010, período denominado Neocolonização de $\mathrm{RH}$, foi crescente a demanda por trabalhadores qualificados, devido à abertura do mercado e à introdução de novas tecnologias. A disseminação da Administração de Recursos Humanos (ARH) estratégica no Brasil ocorre sob a liderança de empresas multinacionais americanas, o que justifica a maior aderência da perspectiva americana no país. Entre os elementos-chave do discurso nesse período estão o gerencialismo e o empreendedorismo, introduzindo-se uma visão das pessoas como empresárias de si mesmas, com livre iniciativa, a partir do movimento das relações humanas (Wood, Tonelli \& Cooke, 2011).

No caso brasileiro, este debate emerge na discussão acadêmica, fundamentado inicialmente na literatura americana, pensando-se competência como input, algo que o indivíduo tem. A introdução de autores franceses como Le Boterf, Zarifian, autores ingleses como Jacques e seus seguidores (Billis e Rowbottom, Stamp e Stamp), contribuem para o enriquecimento conceitual e empírico, gerando novas perspectivas e enfoques (Fleury \& Fleury, 2001, p. 186).

Com os novos estilos gerenciais importados e diante da necessidade de desempenho organizacional, além da indispensável atualização, funções e capacidades mais complexas dos trabalhadores passam a ser valorizadas, tais como raciocínio abstrato, valores, identificação com a empresa, capacidade de guiar-se por objetivos, resolver problemas, criar, levantar alternativas, discordar, etc. O novo modelo de gestão busca, assim, relacionar a competência das pessoas com a estratégia organizacional e com os processos de aprendizagem. (Borges \&Yamamoto, 2014; Leite \& Goulart, 2006).

Pesquisadores da Universidade de São Paulo (USP) estudam uma abordagem que alia as competências individuais com as competências 
organizacionais. Fleury e Fleury (2001) classificam as competências desenvolvidas pelos indivíduos que atuam em uma organização em três grandes blocos: (1) competências de negócio (relacionadas à compreensão do negócio, envolvendo a visão estratégica e o planejamento); competências técnico-profissionais (específicas para certa atividade); (3) competências sociais (necessárias para interagir com as pessoas).

Ao colocarmos organização e pessoas lado a lado, podemos verificar o processo contínuo de troca de competências. A organização transfere seu patrimônio para as pessoas, enriquecendo-as e preparando-as para enfrentar situações profissionais e pessoais, na organização ou fora dela. As pessoas, ao desenvolverem sua capacidade individual, transferem para a organização seu aprendizado, capacitando-a a enfrentar novos desafios (Dutra, 2008, p. 7).

Vieira e Ribeiro da Luz (2005, p. 106) apontam como conclusão de seu estudo que

a melhoria do desempenho tem levado as empresas a modernizarem sua gestão e a apostarem na elevação das competências de seus funcionários, [...] ao mesmo tempo que os diplomas e certificados perdem seu prestígio se não forem complementados pela experiência que, em geral, é mais importante do que a formação acadêmica.

A dimensão experimental, ao contrário, reforça-se com a gestão das competências, pela ênfase atribuída aos saberes, associada a verbos como saber agir, mobilizar recursos, integrar saberes múltiplos e complexos, saber aprender, saber engajar-se, assumir responsabilidades, ter visão estratégica (Fleury \& Fleury, 2001; Vieira \& Ribeiro da Luz, 2005).

A Organização das Nações Unidas para a Educação, a Ciência e a Cultura (Unesco), por meio de sua Comissão Internacional sobre a Educação para o século XXI, presidida por Jacques Delors, em 2010, publica um relatório que estabelece quatro pilares de um novo tipo de educação com enfoque em (1) aprender a conhecer, (2) aprender a fazer, (3) aprender a viver junto e (4) aprender a ser. Considerando o construto competência, ressalta-se o "aprender a fazer", que significa associar a técnica com a aplicação de conhecimentos teóricos, não dissociando o saber e o fazer (Delors, 2010, p. 31). 
Isso posto, torna-se nítida a consolidação do construto competências como diferente de qualificação, pois considera o indivíduo, sua subjetividade e sua experiência, conforme concluem Vieira e Ribeiro Da Luz (2005, p. 106):

\begin{abstract}
A subjetividade dos empregados, fruto de seus valores e crenças, comprometimento e sua solidariedade, bem como de sua capacidade de interagir com os demais atores da organização, de refletir sobre o trabalho, de compreender e interpretar as situações, é mobilizada para produzir os resultados organizacionais desejados, de forma a manter a empresa competitiva. Essa lógica encerra 0 caráter ideológico do discurso das competências e revela que a noção de qualificação vem sofrendo um deslocamento conceitual, que concorre para o fortalecimento (ou consolidação) do conceito de competência.
\end{abstract}

Independentemente da abordagem, verifica-se que o conceito de competência envolve o conhecimento explícito, que é o conhecimento formal sistêmico, pertencente à esfera dos procedimentos empíricos, e o conhecimento tácito, compreendido como um saber arraigado à abstração pessoal, que mobiliza estratégias e raciocínios complexos capazes de gerar a ação necessária em um contexto específico (Leite \& Goulart, 2006).

\title{
2.5. O CENÁRIO CONTEMPORÂNEO DO MUNDO DO TRABALHO E AS
} EMPRESAS DO FUTURO: CARACTERÍSTICAS MENCIONADAS NA LITERATURA

A globalização da economia teve início com o processo de internacionalização do capital, no final do século XIX, integrando o mundo em uma nova rede de relações que, somada ao progresso tecnológico, se fez responsável pelo fortalecimento das grandes empresas. Dessa forma, as organizações puderam adquirir as inovações e expandiram-se além das fronteiras de sua origem. O avanço da globalização e a revolução tecnológica encabeçam, portanto, a lista dos fenômenos que constroem, a partir de então, essa nova configuração. (Goulart \& Guimarães, 2002).

No começo dos anos 1980, iniciam-se mudanças no âmbito social, econômico, político e tecnológico, resultando em um intenso processo de reestruturação da lógica produtiva. Esse novo ambiente desloca as condições decisivas do sucesso empresarial: concorrência local para concorrência mundial; foco da indústria para o cliente; de produtos padronizados para produtos flexíveis e inovadores; de produtos em escala 
para produtos de alta qualidade e preço atrativo (Barbosa \& Cintra, 2012, p. 44).

Outros autores fazem referência, ainda, à influência que essas mudanças na economia mundial exerceram sobre o funcionamento das organizações e afirmam:

Todas essas mudanças no ambiente econômico e empresarial têm se traduzido, no contexto organizacional, em uma série de programas de reestruturação, reflexo da desesperada tentativa das empresas de darem conta de um ambiente que se tornou muito mais complexo, dinâmico e mutável (Birchal \& Muniz, 2002, p. 26).

Confirmando esse ponto de vista, Malvezzi (2014) observa que a globalização faz surgir um novo arranjo caracterizado pela compressão do tempo e do espaço no qual o desempenho é a marca mais visível da sociedade globalizada à qual as pessoas são obrigadas a adaptar-se.

Com o intuito de debater os desafios e dilemas do mundo do trabalho no século XXI, foi feito um estudo que apontou que alguns valores são emergentes e relevantes na sociedade contemporânea:

O mundo globalizado da sociedade do conhecimento trouxe mudanças significativas ao mundo do trabalho. $O$ conceito de emprego está sendo substituído pelo de trabalho. A atividade produtiva passa a depender de conhecimentos, e o trabalhador deverá ser um sujeito criativo, crítico e pensante, preparado para agir e se adaptar rapidamente às mudanças dessa nova sociedade. (...) Nesta conjuntura, em que a mudança tecnológica é a regra, buscar condições para ancorar a preparação do profissional do futuro requer uma estratégia diferenciada (Silva \& Cunha, 2002, p. 77).

Peixoto Filho e Silva (2014) confirmavam, anos depois:

O contexto internacional caracteriza-se pela desregulamentação/ liberalização das economias, pelo aumento da vulnerabilidade externa, pela financeirização da riqueza em detrimento dos produtos e por maior ocorrência de crises sistêmicas. O que se configura é um processo de flexibilização no setor produtivo e nas relações de trabalho, o que acarreta na demanda por uma mão de obra mais flexível e capacitada, com maior acúmulo de habilidades que não são apenas técnicas, mas também sociais (Peixoto Filho \& Silva, 2014, p. 79). 
A sociedade do conhecimento "não é simplesmente uma sociedade de experts, ou uma sociedade que produz conhecimentos incessantemente, mas um espaço em que as culturas do conhecimento se interpenetram e tecem redes de capilaridade" (Fartes, 2008, p. 583). Dessa forma, afeta a vida cotidiana e o mundo do trabalho, gerando tanto admiração pelo avanço científico e tecnológico, quanto "precariedade, instabilidade e vulnerabilidade, entendidos como traços característicos de uma modernidade que se liquefaz, ao diluir as certezas da ilusão moderna no descartável, na performance e na individuação" (Fartes, 2008, p. 583).

A mudança na organização do trabalho exerceu seus efeitos também sobre os modelos de gerenciamento. Chanlat (1996) relata que as formas tradicionais de gestão já vinham sendo substituídas por modos de gestão baseados na excelência, na busca da qualidade total, que enfatizam a supervalorização da ação, o desafio permanente, a adaptabilidade, a polivalência da mão de obra e a suavização das relações hierárquicas.

O entendimento destas mudanças na natureza das organizações é de fundamental importância para que possamos entender a natureza das novas relações de trabalho e o trabalho humano neste novo contexto. Isto é, quais as atitudes e habilidades que passaram a ser requeridas das pessoas que atuam neste novo mundo organizacional em gestação (Birchal \& Muniz, 2002, p. 26).

A capacidade de as pessoas manterem as competências exigidas pelo mercado de trabalho é denominada empregabilidade, conforme descrevem Birchal e Muniz (2002, p. 28):

A relação de trabalho deixa de se basear na fidelidade e passa a basear-se no profissionalismo e na capacidade do trabalhador de se manter atualizado com as necessidades do mercado de trabalho. (...) a nova forma de relacionamento entre patrões e empregados sintetizada no conceito da empregabilidade - abandona - paternalismo das relações de trabalho que caracterizavam as burocracias e adota a responsabilidade compartilhada. A regra agora é a capacitação profissional para toda a vida.

Constata-se então, um novo cenário, caracterizado pela instabilidade, no qual as ambivalências enfatizam a lógica da competência.

O que o mercado de trabalho vai solicitar são profissionais que fazem uso dos recursos de sua 
personalidade. O que buscam os assalariados é uma nova identidade profissional, que dê sentido aos saberes e às competências que adquirem e que aumente suas chances de empregabilidade (Le Boterf, 2003, p. 11).

Zarifian (2001) apresenta três mutações importantes que modificam as características do trabalho: evento, comunicação e serviço. Segundo o autor, o evento é "alguma coisa que sobrevém de maneira parcialmente imprevista, não programada, mas de importância para o sucesso da atividade produtiva", o que chamamos de acaso (Zarifian, 2001, p. 41). Ele modifica a maneira de encarar as aprendizagens profissionais, possibilita uma aprendizagem dinâmica e instiga a busca de uma solução adequada, ou seja, "saber inventar as respostas a serem dadas a um ambiente social complexo e instável" (Zarifian, 2001, p. 42). Com relação à comunicação, Zarifian (2001) constata que essa passa a ser uma questão organizacional central, que ultrapassa a disponibilização de informações e se refere a um entendimento mútuo, cuja qualidade das interações é fundamental para melhorar o desempenho das organizações. Por último, a noção de serviço é definida pelo autor como "uma modificação no estado ou nas condições de atividades de outro ser humano, ou de uma instituição (...); consiste em produzir um serviço para um destinatário" (Zarifian, 2001, p. 48). A noção de serviço insere o cliente ou usuário como prioridade, em detrimento do produto. Portanto, conhecer as necessidades e expectativas desse cliente poderia influenciar na forma de produção e de prestação desse serviço tendo em vista a qualidade e sua satisfação.

Dutra (2008, p. 7) pondera a agregação de valor das pessoas, relacionando-as à competividade das empresas, sendo, portanto, "sua contribuição efetiva ao patrimônio de conhecimentos da organização permitindo-Ihe manter suas vantagens competitivas no tempo". Barbosa e Cintra (2012, p. 39) concordam que "a reflexão quanto aos fatores que asseguram a competitividade, na atualidade, evidencia um movimento que passa a considerar as competências como um diferencial competitivo". Araújo, Silva e Brandão (2015) também destacam que os temas aprendizagem, competências e inovação são recorrentes quando se analisa a competitividade nas organizações. 
Borges e Yamamoto (2014, p. 57) identificam cinco pilares da conjuntura socioeconômica no mundo do trabalho que influenciam e influenciarão as empresas no futuro: (1) mudanças nas noções de espaço (...) possibilitando gerir eventos a distância e pela capacidade de armazenar informações de maneira cada vez mais compacta; (2) alta circulação do capital financeiro e tecnológico, tornando a competição entre as empresas mais intensa e global; (3) aumento da imprevisibilidade dos acontecimentos políticos, sociais e culturais, dificultando a atividade de planejamento; (4) bombardeio de informações e transformação de significados, ampliando a importância da dimensão simbólica; (5) criação da possibilidade de se viverem diferentes identidades.

Kouzes e Posner (2010, p. 29) destacam que a carga de trabalho e a pressão são aspectos presentes e constantes no mundo atual do trabalho e não tendem a diminuir em um futuro próximo, pois "novos avanços em tecnologia nos surpreenderão diariamente $[\ldots]$ e o mundo continuará a enfrentar desafios inesperados".

No cenário contemporâneo do mundo do trabalho "os novos profissionais devem ser capazes de operacionalizar seu conhecimento de modo integrado às suas aptidões e vivências culturais" (Silva \& Cunha, 2002, p. 79).

Com relação ao local de trabalho, o mundo tradicional do escritório (ou da fábrica) é muito diferente das condições e instrumentos encontrados atualmente e influenciados pelas contingências:

A experiência do trabalho se tornou mais complexa porque deixa de estar alocada em um espaço conhecido e visível, de relativamente fácil controle, para ser transferida para o mundo caracterizado pelas propriedades do hipertexto, onde sua ambiguidade e incerteza são exponenciadas. Um dos mais significativos desafios do trabalhador é o enfrentamento rotineiro das descontinuidades que o obrigam a um contínuo ajustamento, para o qual Ihe falta sensibilidade ou apoio institucional" (Malvezzi, 2014, p. 15).

Anunciando o que viria a ocorrer nos anos seguintes, Ulrich e Smallwood (2010, p. 13) relatam que "a organização do futuro existe hoje quando os líderes mudam seu enfoque da estrutura de sua organização para 
o conjunto de competências que a organização precisa para executar a estratégia".

O ponto de vista desses autores é partilhado também por Lawer e Worley (2010, p. 184), segundo os quais, diante da aceleração da velocidade das mudanças, a eficácia organizacional deve ser vista de forma diferente; considera-se "crescente o número de executivos que pedem por mais agilidade, flexibilidade e inovação de suas empresas". Entretanto, os autores ressaltam que as empresas ainda demonstram grande dificuldade de colocar a adaptabilidade em prática, em virtude de buscarem suas vantagens competitivas na estabilidade e na execução (Lawer \& Worley, 2010, p. 185).

Uma habilidade apontada como preciosa por Champy (2010, p. 3) para as empresas do futuro é "enxergar o que os outros não enxergam". Na visão do autor, é importante sintonizar a percepção das empresas com as necessidades do mercado em uma visão aguçada e empreendedora; adaptarse é prerrogativa de sobrevivência no mercado atual, volátil e exigente. As mudanças no mercado devem ser monitoradas e os funcionários devem ser rápidos em identificá-las e comunicá-las (Champy, 2010; Rao, 2010).

Diante das alterações imprevisíveis e frequentes no cenário organizacional ao qual o indivíduo que administra sua vida profissional está sujeito, este é obrigado a reorientar sua identidade, suas atitudes, metas, rotinas e redes sociais, o que é chamado de sujeito empreendedor. Para Filion (1999), o empreendedor é um indivíduo criativo, capaz de delimitar e atingir objetivos e que está sempre atento às oportunidades do ambiente. Malvezzi (1999) considera empreendedor aquele trabalhador que atua como agente econômico reflexivo, que produz valor econômico a partir de sua atividade. 0 "agente econômico reflexivo é aquele profissional que se reinventa a si mesmo, agindo de tal modo que os outros confiem nele e vejam vantagens em se associar a ele" (Malvezzi, 1999, p. 66). Além da formação do empreendedor, seu comportamento pode estar atrelado a características subjacentes que emergem no contexto profissional e que, diante de situações inusitadas, podem comprometer os resultados (Minello, Scherer \& Alves, 2012).

São propostas cinco capacidades que as organizações do futuro devem demonstrar para operar no mundo dos negócios do amanhã: talento, 
liderança, agilidade, conexão "de fora para dentro" e propósito (Ulrich \& Smallwood, 2010, p. 13).

A análise da literatura sobre o tema liderança na empresa moderna sugere alterações relacionadas à visão anterior. Atualmente, liderança não se resume ao tradicional cargo ocupado por determinada pessoa; ela passa a incluir a referência a profissionais mais qualificados, capazes de tomar decisões complexas em situações de pressão e grande responsabilidade. Esses profissionais devem envolver sua equipe, ser capazes de promover a instrução, o aconselhamento, despertar o entusiasmo e manter um clima saudável no ambiente de trabalho. Líderes devem ainda constituir o elo da missão da empresa com a linha de frente, compreender a necessidade de a empresa compartilhar sua visão com os funcionários a fim de despertar um sentimento de pertença, aventando a possibilidade de uma construção em conjunto. Os líderes do futuro deverão ser capazes de dar autonomia e voz a seus liderados (Drucker, 1997; Harmon, 1997; Somerville \& Mroz, 1997; Gergen \& Vanourek, 2010; Kouzes \& Posner, 2010; Rao, 2010).

O gerente (empreendedor) trabalha com incertezas, criando inovações, mudando a equação da função de produção (capital-trabalho). Seu ato gerencial é idiossincrático. Pode-se dizer, então, com base nos pensamentos de Schumpeter, que a ideia de inovação está sempre ligada a mudanças, a novas combinações de fatores que rompem com o equilíbrio existente (Barbosa \& Cintra, 2012, p. 34)

Outra modificação significativa no mercado de trabalho contemporâneo relaciona-se à expectativa dos profissionais com relação ao trabalho, conforme apresentado no Quadro 3, a seguir.

\begin{tabular}{|llll|}
\hline EXPECTATIVAS & GERAÇÃO BB & GERAÇÃO X & GERAÇÃ O Y \\
\hline Vínculo & Empresa & Equipes & Projetos \\
Remuneração & Fixa, isonomia & Fixa + Variável & Variável, resultado \\
Ambiente & Formal & Moderado & Informal \\
Controle & Horários & Horários + Resultado & Resultado \\
Hierarquia & Alta & Média & Baixa \\
Informação & Vertical & Seletiva & Horizontal \\
Discurso & Velado & Estratégico & Transparente \\
\hline \hline
\end{tabular}

\section{Quadro 3: Expectativas das gerações sobre trabalho e carreira}

Fonte: Calvosa et al. (2012, p. 12) 
"A diversão, o clima leve e descontraído também serão bastante valorizados pelos funcionários e podem contribuir para 0 seu comprometimento a longo prazo" (Rao, 2010, p. 40). Com relação à aprendizagem, Rao (2010) destaca que é importante empreender esforços tanto no âmbito do funcionário (vontade de aprender) quanto da empresa em oferecer um ambiente desafiador que incentive o aperfeiçoamento de suas habilidades e ferramentas.

A criatividade, a inovação e o fato de ser visionário são apontadas também como vantagens para as empresas no mercado. Por serem mais perspicazes, as empresas criativas estão crescendo mais rapidamente que seus concorrentes, pensam de forma inovadora e podem simplificar os problemas complexos para seus consumidores (Champy, 2010; Kouzes \& Posner, 2010).

Vislumbrar possibilidades é uma competência altamente valorizada nas lideranças das empresas e alimentam a inovação, porém, é dificultada pela velocidade das mudanças, pela complexidade dos problemas e pela incerteza; portanto, ainda precisa ser muito desenvolvida. Apesar da dificuldade de colocarem esses novos conceitos em prática, os líderes empresariais atuais não têm outra escolha a não ser tomar decisões em mundo complexo e de ritmo acelerado de mudanças, porque a administração "à moda antiga" não é mais eficiente, foram rompidos os limites de tempo, espaço e idioma; dos setores e segmentos de mercado; e dos setores público, privado e social (Drucker, 1997; Harmon, 1997; Somerville \& Mroz, 1997).

Somerville e Mroz (1997) apresentaram uma perspectiva de que uma organização bem-sucedida no século XXI seria aquela que abordasse a solução de problemas e cuja postura esperada deveria ser a de verificar as alternativas e possibilidades, inclusive as relacionadas ao atendimento de eventuais necessidades dos funcionários e à tomada de decisão como busca universal de aprendizado. Segundo os autores, aspectos como a flexibilidade e a adaptabilidade são relevantes e devem ser considerados na empresa do futuro (Rao, 2010, p. 41). No novo modelo de comunicação, a organização hierarquizada, baseada em caixinhas não é mais adequada, a gestão precisa ser partilhada, a comunicação precisa ocorrer em todos os sentidos (Zarifian, 2001). 
A organização do século XXI se caracteriza pela responsabilidade, pela autonomia, pelo risco e pela incerteza. Talvez não seja um ambiente tranquilo, mas é muito humano. Acabaram a rigidez e a disciplina artificiais da empresa convencional. Em seu lugar, existe um mundo cheio de confusões, desafios e insucessos característicos do mundo verdadeiramente humano (Hammer, 1997, p. 48).

Mais recentemente, Gergen e Vanourek (2010, p.162) apontam ainda tendências emergentes que definirão a organização do futuro: (1) o desmembramento de pessoas, equipes e organizações das instituições e estruturas tradicionais formando novas configurações cada vez mais virtuais; (2) a autenticidade, a valorização das próprias ideias, o uso de seu potencial em um trabalho que faça sentido, escolhas baseadas em valores e prioridades; (3) a integração, ou seja, a restauração da coerência e da congruência na vida, menos ênfase no rendimento e mais no aprendizado, desafio, realização pessoal e até mesmo diversão, aproximando a atuação profissional da vida pessoal.

A fim de ressaltar a identificação das competências relevantes para as empresas do futuro, no Quadro 3 correlacionam-se características do cenário contemporâneo que influenciam o mundo do trabalho com as competências apresentadas na literatura como necessárias para lidar com tal realidade.

\begin{tabular}{|c|c|}
\hline Cenário contemporâneo & Competências requeridas \\
\hline 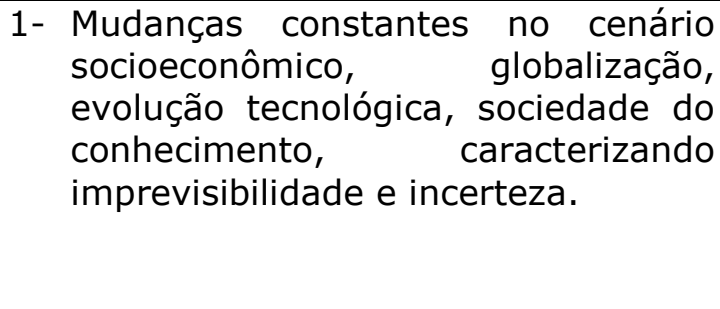 & $\begin{array}{l}\text { Adaptabilidade, flexibilidade para lidar } \\
\text { com a instabilidade e a vulnerabilidade. } \\
\text { Capacidade de enfrentar novos } \\
\text { desafios, manter o acesso à informação } \\
\text { e ao entendimento do mundo. }\end{array}$ \\
\hline
\end{tabular}

(continua)

(continuação)

2- Modificação na noção de tempo e espaço, que passam a ter novas configurações para além dos espaços físicos determinados. Com a disponibilidade de acesso aos recursos virtuais e digitais cada vez
Capacidade de gerir a distância e de armazenar informações de maneira cada vez mais compacta, interatividade, iniciativa. 


\begin{tabular}{|c|c|c|}
\hline & $\begin{array}{l}\text { maior, à mão e a qualquer tempo, } \\
\text { foram rompidos os limites de tempo, } \\
\text { espaço e idioma. }\end{array}$ & $\begin{array}{l}\text { Comprometimento das pessoas para } \\
\text { resultados: agilidade, conexão com o } \\
\text { mundo virtual, disposição para } \\
\text { aprendizagem permanente, dedicação. }\end{array}$ \\
\hline & $\begin{array}{l}\text { Migração do conceito de emprego } \\
\text { formal para trabalho, com o } \\
\text { crescimento dos trabalhos } \\
\text { descontínuos, informais, autônomos. } \\
\text { Aumento de empreendedores e } \\
\text { carreira em espiral. }\end{array}$ & $\begin{array}{l}\text { Desenvolvimento de competências } \\
\text { individuais como autonomia, } \\
\text { empreendedorismo, criatividade, } \\
\text { iniciativa, análise e crítica. Capacidade } \\
\text { do trabalhador de se manter atualizado } \\
\text { com as necessidades do mercado de } \\
\text { trabalho. Resiliência, capacidade de } \\
\text { reinventar-se a si mesmo. }\end{array}$ \\
\hline & $\begin{array}{l}\text { Novos modelos de gestão e novas } \\
\text { configurações organizacionais que } \\
\text { mudam seu enfoque da estrutura } \\
\text { organizacional tradicional para o } \\
\text { conjunto de competências que a } \\
\text { organização precisa para executar a } \\
\text { estratégia, valorização do capital } \\
\text { humano. Suavização das relações } \\
\text { hierárquicas. }\end{array}$ & $\begin{array}{l}\text { Proatividade, inovação. Capacidade dos } \\
\text { profissionais de guiar-se por objetivos, } \\
\text { de resolver problemas, discordar, } \\
\text { analisar, criar e levantar alternativas. } \\
\text { Escolha de um trabalho que faça } \\
\text { sentido, escolhas baseadas em valores } \\
\text { e prioridades. }\end{array}$ \\
\hline & $\begin{array}{l}\text { Novas gerações, suas expectativas } \\
\text { de trabalho e carreira que } \\
\text { provocarão mudanças no ambiente } \\
\text { interno das empresas. }\end{array}$ & $\begin{array}{l}\text { Produtividade, remuneração variável } \\
\text { por resultados, ambiente informal. } \\
\text { Constante reciclagem dos } \\
\text { conhecimentos, colocar em prática o } \\
\text { que aprendem, se tornarem cada vez } \\
\text { mais hábeis e não terem medo de ter } \\
\text { atitude. }\end{array}$ \\
\hline & $\begin{array}{l}\text { Novas formas de atuação das } \\
\text { lideranças }\end{array}$ & $\begin{array}{l}\text { Líderes capazes de tomarem decisões } \\
\text { complexas em situações de pressão e } \\
\text { grande responsabilidade, de } \\
\text { vislumbrarem possibilidades de } \\
\text { solução. Devem ser capazes de } \\
\text { promover a instrução, o } \\
\text { aconselhamento, despertar o } \\
\text { entusiasmo e manter um clima } \\
\text { saudável no ambiente de trabalho, dar } \\
\text { autonomia e voz aos liderados, } \\
\text { estimular um sentimento de pertença. }\end{array}$ \\
\hline
\end{tabular}




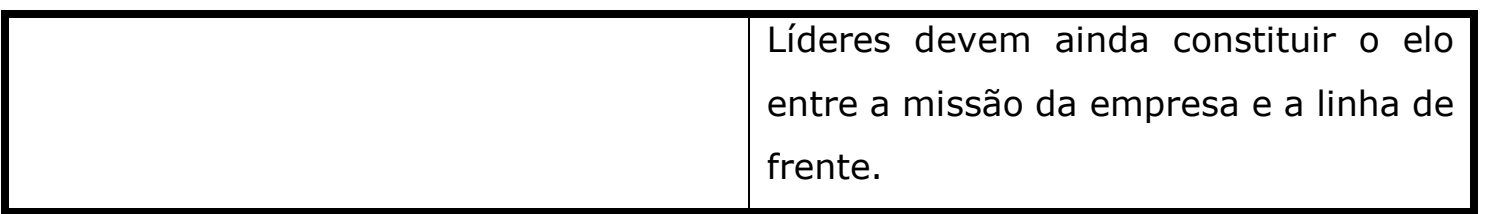

\section{Quadro 4: Cenário contemporâneo e as competências requeridas dos profissionais}

Fonte: Elaborado pela autora

\section{CONSIDERAÇÕES FINAIS}

A caracterização do cenário do mundo do trabalho no momento em que este texto foi produzido pode ser sintetizada do seguinte modo: a globalização da economia, aliada ao desenvolvimento tecnológico ocorrido a partir de meados do século XX, tornaram-se responsáveis por mudanças nas organizações, nas relações e nas condições do trabalho. A qualificação profissional, adotada inicialmente como forma de promover o melhor aproveitamento das pessoas no mundo do trabalho, aparece como um sistema limitado por não acompanhar as exigências de adaptação da mão de obra às novas formas de produção. Essas mudanças exercem uma influência relevante sobre o que passa a ser esperado do trabalhador e surge a noção de competências exigidas do trabalhador, construto que sugere que se devam identificar conhecimentos, habilidades e atitudes que favoreçam 0 desempenho dos profissionais que estão atuando e virão a atuar no mercado de trabalho nos próximos anos.

Vale destacar que o conceito de competência contempla a importância do conhecimento e da qualificação, envolve o conhecimento explícito, que é o conhecimento formal sistêmico exigido na qualificação, e agrega o conhecimento tácito, compreendido como um saber arraigado à abstração pessoal, que mobiliza estratégias e raciocínios complexos capazes de gerar a ação necessária em um contexto específico. Portanto, a noção de competência surge para além dos conhecimentos e remete a uma mistura de saber e agir mediante a aquisição de novas experiências, em determinados contextos que possibilitem a aprendizagem e o acúmulo de bagagem profissional. Diante disso, quanto mais desafios um profissional se propuser 
a enfrentar, mais situações se permitirá vivenciar, mais competências poderá desenvolver e mais recursos terá para lidar com situações futuras. Logo, o conceito de competência veio a acrescer um novo sentido às exigências advindas da mudança do cenário contemporâneo e sua influência sobre o trabalho.

As competências convergem, pois, para a capacidade de mobilizar recursos para agir diante da imprevisibilidade do mercado. As mudanças constantes no cenário socioeconômico, marcadas pela globalização da economia e pela evolução tecnológica, passarão a exigir dos profissionais habilidades como flexibilidade para enfrentá-las.

A vida organizacional, cuja transformação aponta para novas configurações, passa a requerer modelos de gestão marcados pela inovação, pela influência de tempos e espaços variáveis, pela capacidade de encarar novos desafios e pela suavização hierárquica. Esse conjunto de mudanças sugere uma atuação mais eficiente da liderança, capaz de perseguir os objetivos organizacionais sem perder de vista o bem-estar e o interesse do trabalhador. Nesse sentido, os líderes do mundo contemporâneo precisam desenvolver competências como iniciativa, proatividade, inovação, adaptabilidade, capacidade de dar autonomia e voz aos liderados, e desenvolver nos liderados um sentimento de pertença, despertar o entusiasmo e manter um clima saudável no ambiente de trabalho.

Todos esses aspectos culminam na valorização do capital humano, tão citada nos textos que apontam a característica do mundo contemporâneo, propondo a seleção e a retenção de talentos, o incentivo à aprendizagem contínua e a condição de gerar resultados efetivos para a empresa.

A aceleração da dinâmica do processo de desenvolvimento e sua influência sobre o funcionamento das organizações, as turbulências geradas e a complexidade do contexto constituem fatos inexoráveis. O desafio, dessa forma, conecta-se com a estratégia, com a prospecção do futuro, com a gestão de pessoas e com os inúmeros desafios advindos dessa transformação. Dessa forma, as competências citadas pelos autores mencionados neste texto tendem a aumentar a empregabilidade dos profissionais, uma vez que se compatibilizam com a necessidade de adaptação das empresas do futuro. Infere-se, pois, que essas competências, 
especialmente aquelas relacionadas com os desafios dos cenários futuros dos mercados, conforme consolidadas no Quadro 3, terão sua relevância ampliada no cenário do futuro.

A noção de competência veio ampliar e até mesmo substituir em importância a noção de qualificação, pois as pessoas não enriquecem o capital intelectual de uma organização apenas em razão de sua qualificação expressa pelo diploma, mas principalmente por suas características pessoais que contribuem para o crescimento organizacional. Nesse sentido, o conceito francês de competência, cujas raízes são encontradas na crítica dos trabalhadores no final da década de 1960, parece dominar o contexto organizacional contemporâneo, uma vez que empresas como a Apple, a Google, as produtoras de veículos automotores, entre outras, estão em busca desses talentos capazes de alavancar seu desenvolvimento.

O novo modelo de gestão, que busca relacionar a competência das pessoas com a estratégia organizacional e com os processos de aprendizagem, precisa adaptar-se também à transformação de significados, buscar condições de apoiar seus funcionários e ancorar a preparação desses profissionais do futuro, o que irá requerer uma estratégia diferenciada. As empresas do futuro precisarão oferecer um ambiente desafiador, que incentive $o$ aperfeiçoamento das habilidades e ferramentas de seus funcionários, assim como as atitudes empreendedoras, com livre iniciativa em busca de melhores resultados e manutenção da competitividade.

O objetivo deste artigo se ateve a uma reflexão teórica sobre quais competências serão as mais relevantes para profissionais e empresas no futuro, identificando nos construtos acadêmicos contribuições aos profissionais e aos gestores em organizações sobre um cenário atual e suas tendências apontadas na literatura. O artigo culmina com a identificação da necessidade de revisão das competências requeridas dos profissionais nos próximos anos, o que implica uma nova postura/proposta dos diversos elos do mundo do trabalho, que pede mais agilidade, flexibilidade, adaptabilidade e inovação tanto no âmbito das empresas quanto dos profissionais. Fica, portanto, a recomendação de novos estudos, principalmente no que tange a pesquisas de campo para discutir e apontar de forma aplicada as competências mais relevantes requeridas dos profissionais nos próximos 
anos. Dessa forma, espera-se que o presente estudo sirva de estímulo ao debate e à pesquisa acerca do futuro das organizações, dos profissionais e das competências para o mercado futuro.

\section{REFERÊNCIAS}

Araújo, G. D., Silva, A. B. da, \& Brandão, J. M. F. (2015, abril/junho). O que revela a literatura internacional sobre os vínculos entre aprendizagem, competências e inovação? Revista de Administração e Inovação, 12(2), 737. Recuperado em 10 de setembro, 2015, de www.revistarai.org/rai/article/download/1190/pdf

Barbosa, A. C. Q., \& Cintra, L. P. (2012, janeiro/junho). Inovação, competências e desempenho organizacional - articulando construtos e sua operacionalidade. Future Studies Research Journal: Trends and Strategies, 4(1), 31-60.

Birchal, S. de O., \& Muniz, R. M. (2002). A lógica do capitalismo e o trabalho humano. In I. B. Goulart (Org.), Psicologia organizacional e do trabalho: teoria, pesquisa e temas correlatos (pp. 23-36). São Paulo: Casa do Psicólogo.

Borges, L. de O., \& Yamamoto, O. H. (2014). O mundo do trabalho. In C. Zanelli, J. E. Borges-Andrade, \& A. V. B. Bastos (Orgs.), Psicologia, organizações e trabalho no Brasil (2a. ed., pp. 25-68). Porto Alegre: Artmed.

Calvosa, M., Vilhena, T., Xavier, A., \& Xavuem, L. (2012). Desenvolvimento pessoal e profissional de futuros gestores: como a geração $Y$ encara as competências necessárias para o aumento da empregabilidade e para o sucesso no ambiente profissional. Anais do Encontro Anual da Associação 
Nacional de Pós-Graduação e Pesquisa em Administração, 36, Rio de Janeiro, RJ, Brasil.

Champy, J. (2010). Supere seus rivais vendo o que os outros não veem. In F. Hesselbein, \& M. Goldsmith, A nova organização do futuro: visões, estratégias e insigths dos maiores líderes do pensamento estratégico (pp. 3-12). Rio de Janeiro: Elsevier.

Chanlat, J. F. (1996). O indivíduo na organização: dimensões esquecidas. São Paulo: Atlas.

Delors, J. (Coord.). (2010). Os quatro pilares da educação. In J. Delors, Educação: um tesouro a descobrir. São Paulo: Cortez.

Drucker, P. (1997). Introdução - rumo à nova organização. In F. Hesselbein, M. Goldsmith, \& R. Beckhard, A organização do futuro: como preparar hoje as empresas de amanhã (pp. 15-19). São Paulo: Futura.

Dugué, E. (2004). A lógica da competência: o retorno do passado. In A. Tomasi (Org.), Da qualificação à competência (pp. 19-32). Campinas, SP: Papirus.

Dutra, J. S. (2004). Competências: conceitos e instrumentos para gestão de pessoas da empresa moderna. São Paulo: Atlas.

Dutra, J. S. (2008). Estudo prospectivo do setor siderúrgico. Brasília: CGEE.

Dutra, J. S., Fleury, M. T., \& Ruas, R. (2008). Competências: conceitos, métodos e experiências. São Paulo: Atlas.

Fartes, V. L. B. (2008, setembro/dezembro). Formação profissional, profissões e crise das identidades na sociedade do conhecimento. Cadernos de Pesquisa, 38(135), 583-585.

Filion, L. J. (1999, abril/junho). Empreendedorismo: empreendedorismo e proprietários-gerentes de pequenos negócios. Revista de Administração de Empresas - RAE, 34(2), 5-28.

Fleury, M. T. L., \& Fleury, A. (2001). Construindo o conceito de competência. Revista de Administração Contemporânea - RAC, 5(edição especial), 1831961. Recuperado em 20 de março, 2014, de http://www.scielo.br/scielo.php?script=sci_arttext\&pid=S1415$65552001000500010 \&$ Ing $=$ en\&nrm $=$ iso

Fleury, M. T. L., \& Fleury, A. (2001). Apresentação. In P. Zarifian, Objetivo: competência. Por uma nova lógica. São Paulo: Atlas.

Garcia, S. R. de O. (2000, setembro). O fio da história: a gênese da formação profissional no Brasil. Núcleo de Estudos da UFMG. Belo Horizonte: Unisinos, n. 2. Recuperado em 12 de fevereiro, 2015, de http://www.anped. org.br/reunioes/23/textos/0904t. PDF 
Gergen, C., \& Vanourek, G. (2010). Organizações dinâmicas para uma época empreendedora. In F. Hesselbein, \& M. Goldsmith, A nova organização do futuro: visões, estratégias e insigths dos maiores líderes do pensamento estratégico (pp. 155-169). Rio de Janeiro: Elsevier.

Goulart, I. B., \& Guimarães, R. F.(2002). Cenários contemporâneos do mundo do trabalho. In I. B. Goulart (Org.), Psicologia organizacional e do trabalho: teoria, pesquisa e temas correlatos (pp.9-22). São Paulo: Casa do Psicólogo.

Hammer, M. (1997). A essência da nova organização. In F. Hesselbein, M. Goldsmith, \& R. Beckhard, A organização do futuro: como preparar hoje as empresas de amanhã (pp. 41-48). São Paulo: Futura.Harmon, F. G. (1997). O presente do futuro. In F. Hesselbein, M. Goldsmith, \& R. Beckhard, A organização do futuro: como preparar hoje as empresas de amanhã (pp. 260-269). São Paulo: Futura.

Hirata, H. (1994). Da polarização das qualificações ao modelo da competência. In J. C. Ferretti et al. (Orgs.), Novas tecnologias, trabalho e educação: um debate multidisciplinar (pp. 128-137). Petrópolis: Vozes.

Hirata, H. (2001). Entre trabalho e organização, a competência. In P. Zarifian, Objetivo: competência. Por uma nova lógica (pp. 13-19). São Paulo: Atlas.

Kouzes, J. M., \& Posner, B. Z. (2010). A missão do líder: crie um senso compartilhado de destino. In F. Hesselbein, \& M. Goldsmith, $A$ nova organização do futuro: visões, estratégias e insigths dos maiores líderes do pensamento estratégico (pp. 27-35). Rio de Janeiro: Elsevier.

Lawer, E. E., III, \& Worley, C. G. (2010). Desenhando organizações feitas para mudar. In F. Hesselbein, \& M. Goldsmith, $A$ nova organização do futuro: visões, estratégias e insigths dos maiores líderes do pensamento estratégico (pp. 184-198). Rio de Janeiro: Elsevier.

Le Boterf, G. (1995). De la compétence - essai sur un attracteur étrange. Paris: Les Éditions d'Organisations.

Le Boterf, G. (2003). Desenvolvendo a competência dos profissionais. Porto Alegre: Artmed.

Le Boterf, G. (2006). Avaliar a competência de um profissional: três dimensões a explorar. Reflexão $R H, 61-63$. Recuperado em 16 de junho, 2015, de http://www.guyleboterfconseil.com/Article\%20evaluation\%20version\%20directe\%20Pessoal.pdf

Leite, A. C., \& Goulart, I. B. (2006). Competência na perspectiva do trabalho. In I. B. Goulart (Org.), Temas de Psicologia e Administração.(pp. 9-22). São Paulo: Casa do Psicólogo.

Lombardia, P. G., Stein, G., \& Pin, J. R.(2008, mayo). Politicas para dirigir a los nuevos professionales: motivaciones y valores de la generacion $Y$. Documento de investigación. DI-753. 
Malvezzi, S. (1999). Empregabilidade e carreira. Cadernos de Psicologia Social do Trabalho, 2(1), 55-72.

Malvezzi, S. (2014). Prefácio. In C. Zanelli, J. E. Borges-Andrade, \& A. V. B. Bastos (Orgs.), Psicologia, organizações e trabalho no Brasil (2a. ed., pp.13-22). Porto Alegre: Artmed.

Manfredi, S. M. (1999, setembro). Trabalho, qualificação e competência profissional - das dimensões conceituais e políticas. Educação \& Sociedade, 19(64), 13-49. Recuperado em 15 de março, 2015, de http://www.scielo.br/scielo.php?script=sci_arttext\&pid=S0101$73301998000300002 \& \operatorname{lng}=\mathrm{en} \& \mathrm{nrm}=$ iso

McClelland, D. C. (1973, January). Testing for competence rather than for "intelligence". American Psychologist, 28(1), 1-14. Recuperado em 20 de junho, 2015, http://mohandasmohandas.com/african1/ap7301001(1).pdf

Minello, I. F., Scherer, L. A., \& Alves, L. C. (2012). Competências do empreendedor: uma análise com empreendedores que vivenciaram o insucesso empresarial. Revista de Negócios, 17(4), 74-90.

Peixoto Filho, J. P., \& Silva, C. R. C. (2014, setembro/dezembro). Interrelações entre trabalho, educação profissional e desenvolvimento. Trabalho\& Educação, 23(3), 71-85.

Perrenoud, P. (1999). Construir as competências desde a escola. Porto Alegre: Artes Médicas Sul.

Ramos, M. N. (2006). A pedagogia das competências: autonomia ou adaptação? São Paulo: Cortez.

Rao, S. S. (2010). Um tipo diferente de empresa. In F. Hesselbein, \& M. Goldsmith, A nova organização do futuro: visões, estratégias e insigths dos maiores líderes do pensamento estratégico (pp. 36-46). Rio de Janeiro: Elsevier.

Sá, P., \& Paixão, F. (2013). Contributos para a clarificação do conceito de competência numa perspetiva integrada e sistémica. Revista Portuguesa de Educação, 26(1), 87-114.

Silva, E. L. da, \& Cunha, M. V. da. (2002, setembro/dezembro). A formação profissional no século XXI: desafios e dilemas. Ci. Inf., 31(3), 77-82.

Somerville, I., \& Mroz, J. E. (1997). Novas competências para um novo mundo. In F. Hesselbein, M. Goldsmith, \& R. Beckhard, A organização do futuro: como preparar hoje as empresas de amanhã (pp. 84-98). São Paulo: Futura.

Spencer, L. M., McClelland, D. C., \& Spencer, S. (1994). Competency assessment methods: history and state of the art. Boston: Hay Mc BerResearch Press. 
Ulrich, D., \& Smallwood, N. (2010). A organização não é estrutura e sim capacidade. In F. Hesselbein, \& M. Goldsmith, A nova organização do futuro: visões, estratégias e insigths dos maiores líderes do pensamento estratégico (pp. 13-26). Rio de Janeiro: Elsevier.

Vieira, A., \& Ribeiro da Luz, T. (2005, abril/junho), Do saber aos saberes: comparando as noções de qualificação e de competência. O\&S, 12(33), 93-108.

Wood Jr, T., Tonelli, M. J., \& Cooke, B. (2011, maio-junho). Colonização e neo-colonização da gestão de recursos humanos (GRH) no Brasil (19502010). Revista de Administração de Empresas- RAE, 51(3), 232-243.

Zarifian, P. (2012). Objetivo competência. Por uma nova lógica. São Paulo: Atlas. 